\title{
Aplikasi Pupuk Organik Cair dan Pupuk Anorganik terhadap Pertumbuhan, Produksi, dan Kualitas Pascapanen Jagung Manis (Zea mays var. saccharata Sturt.)
}

\author{
Application of Organic-Liquid Fertilizer and Inorganic Fertilizer on Growth, \\ Production, and Postharvest Quality of Sweetcorn (Zea mays var. saccharata Sturt.) \\ Darwin H. Pangaribuan ${ }^{1 *}$, Yohannes Cahya Ginting ${ }^{1}$, Lucky Purwa Saputra ${ }^{2}$, \\ dan Hairani Fitri ${ }^{2}$
}

Diterima 19 Desember 2016/Disetujui 22 Februari 2017

\begin{abstract}
The aim of experiment is to determine the effect of application of organic-liquid fertilizer and inorganic fertilizer recommendation (Urea, $\mathrm{SP}-36$ and $\mathrm{KCl}$ ) on growth, yield, and post-harvest quality of sweet corn ( $\underline{\text { Zea }} \underline{\text { mays }}$ var. saccharata Sturt.) Talenta variety. The experiment was conducted in Kota Sepang Jaya, Bandar Lampung, Lampung Province in December 2015 to March 2016. The experiment used Randomized Block Design (RBD) with six level of treatments and three replications. Treatments were (L1) control/without fertilizer; (L2) inorganic fertilizer 100\% recommendation; (L3) organic-liquid fertilizer; (L4) organic-liquid fertilizer + inorganic fertilizer $100 \%$ recommendation; (L5) organic-liquid fertilizer + inorganic fertilizer 60\% recommendation; and (L6) organic-liquid fertilizer + inorganic fertilizer $20 \%$ recommendation. The use of organicliquid fertilizer, inorganic fertilizer recommendation, or both combinations on sweet corn Talenta variety showed higher growth, yield, and postharvest quality than without fertilizer treatment. The combination of organic-liquid fertilizer and inorganic fertilizer (Urea, SP-36 and KCl) 20\% recommendation can be an alternative package economical for producing sweetcorn. This treatment also showed the lowest storage loss when compared to other treatments.
\end{abstract}

Keywords: biofertilizer, urea, $\mathrm{SP}-36, \mathrm{KCl}$, Talenta

\begin{abstract}
ABSTRAK
Percobaan ini bertujuan untuk mengetahui pengaruh aplikasi pupuk organik cair dan rekomendasi pemupukan anorganik (Urea, SP-36 dan $\mathrm{KCl}$ ) terhadap pertumbuhan, produksi, dan kualitas pasca panen jagung manis (Zea mays var. saccharata Sturt.) varietas Talenta. Penelitian dilakukan di Kota Sepang Jaya, Labuhan Ratu, Bandar Lampung, Provinsi Lampung pada bulan Desember 2015 sampai Maret 2016. Percobaan menggunakan Rancangan Acak Kelompok (RAK) 1 faktor dengan 6 taraf perlakuan dan tiga ulangan. Susunan perlakuan adalah (L1) kontrol (tanpa pupuk); (L2) pupuk anorganik 100\% rekomendasi; (L3) pupuk organik cair; (L4) pupuk organik cair + pupuk anorganik 100\% rekomendasi; (L5) pupuk organik cair + pupuk anorganik $60 \%$ rekomendasi; dan (L6) pupuk organik cair + pupuk anorganik 20\% rekomendasi. Penggunaan pupuk organik cair, rekomendasi pemupukan anorganik, atau kombinasi keduanya menghasilkan pertumbuhan yang lebih tinggi, hasil, dan kualitas pascapanen yang lebih baik daripada perlakuan tanpa pupuk. Kombinasi pupuk organik cair dan pupuk anorganik (Urea, SP-36 dan $\mathrm{KCl}$ ) $20 \%$ rekomendasi dapat menjadi pupuk ekonomis alternatif untuk menghasilkan jagung manis yang optimum dan juga perlakuan tersebut menunjukkan penyusutan bobot tongkol yang terendah jika dibandingkan dengan perlakuan lain.
\end{abstract}

Kata kunci: pupuk hayati, urea, SP-36, KCl, Talenta

\footnotetext{
${ }^{1}$ Dosen Jurusan Agronomi Hortikultura, Fakultas Pertanian, Universitas Lampung

Jalan Sumantri Brojonegoro 1, Bandar Lampung 35145, Indonesia

${ }^{2}$ Alumni Jurusan Agroteknologi, Fakultas Pertanian, Universitas Lampung

Email: darwin.pangaribuan@fp.unila.ac.id (*penulis korespondensi)
} 


\section{PENDAHULUAN}

Jagung manis atau sweetcorn (Zea mays var. saccharata Sturt.) adalah tanaman sayuran komersial yang banyak digemari konsumen, karena memiliki rasa yang manis, serta mengandung vitamin dan nutrisi yang baik bagi kesehatan. Produktivitas jagung manis di Provinsi Lampung pada tahun 2015 adalah 5.12 ton ha $^{-1}$ (Badan Pusat Statistik, 2015), produktivitas ini sedikit lebih rendah dari rata-rata nasional 5.18 ton $\mathrm{ha}^{-1}$ dan jauh lebih rendah dari potensi produksi yang dapat mencapai 15 - 20 ton ha ${ }^{-1}$. Salah satu faktor penyebab rendahnya produktivitas jagung manis adalah teknik budidaya yang masih konvensional dan kurangnya ketersediaan unsur hara dalam tanah. Tanah dapat menyediakan hara yang cukup bagi tanaman budidaya dengan penambahan pupuk organik.

Penambahan unsur hara melalui pemupukan dapat menggantikan unsur hara yang hilang akibat erosi dan tercuci. Utomo $e t$ al. (2016) menguraikan bahwa pupuk yang umum dikenal ada dua jenis yaitu pupuk organik dan pupuk anorganik. Pupuk anorganik adalah pupuk sintetis yang dibuat oleh industri pabrik, sedangkan pupuk organik adalah pupuk kimia hasil fermentasi bahanbahan alam. Pemupukan secara berimbang dan rasional merupakan kunci keberhasilan peningkatan produktivitas jagung.

Pupuk organik cair merupakan salah satu komponen penting dalam pertanian organik. Pupuk organik cair mengandung banyak unsur hara makro, mikro, hormon, dan asam amino yang dibutuhkan tanaman. Selain itu didalam pupuk organik cair terdapat mikroorganisme yang akan memperbaiki kesuburan tanah sehingga dapat menunjang pertumbuhan dan perkembangan tanaman. Penelitian pupuk organik hayati yang mengandung mikroba bakteri telah meningkatkan hasil pada tanaman teh (Wachjar et al., 2006), kacang buncis (Ramana et al., 2011), tomat (Mihov dan Tringovska, 2010) dan kubis (Datta et al., 2009). Penelitian ini bertujuan untuk mengetahui pengaruh aplikasi pupuk organik cair dan rekomendasi pemupukan anorganik (Urea, SP36 dan $\mathrm{KCl}$ ) terhadap pertumbuhan, produksi, dan kualitas pasca panen jagung manis (Zea mays var. saccharata Sturt.) varietas Talenta.

\section{BAHAN DAN METODE}

Percobaan ini dilaksanakan di lahan Kelurahan Kota Sepang Jaya, Kecamatan Labuhan Ratu, Kota Bandar Lampung pada Desember 2015 sampai Maret 2016. Lahan percobaan tergolong tanah dengan ordo Ultisol.

Bahan-bahan yang digunakan pada percobaan ini adalah benih jagung manis varietas Talenta, pupuk anorganik (Urea, SP36 , dan $\mathrm{KCl}$ ), dan pupuk organik cair dengan merk dagang "Bionutri". Pupuk organik cair Bionutri menurut deskripsinya memiliki kandungan mineral (N, P, K, Mg, Ca, S, Na, $\mathrm{Fe}, \mathrm{Mn}, \mathrm{Zn}, \mathrm{Cu}, \mathrm{B}, \mathrm{Al}$, dan $\mathrm{Mo}$ ); asam amino; hormon Gibbrellin, Zeatin, dan IAA; dan mikroba (Azotobacter, Azospirillium, Aspergillus, Lactobacillus, Mychoriza, Rhyzobium, dan Saccharomyces).

Percobaan ini menggunakan Rancangan Acak Kelompok (RAK) 1 faktor dengan 6 taraf perlakuan yang diulang tiga kali. Perlakuan-perlakuan tersebut adalah sebagai berikut:

L1 = Kontrol (tanpa pupuk)

L2 = Pupuk anorganik dengan dosis: Urea $300 \mathrm{~kg} \mathrm{ha}^{-1}, \mathrm{SP}-36150 \mathrm{~kg} \mathrm{ha}^{-1}$, dan $\mathrm{KCl} 100 \mathrm{~kg} \mathrm{ha}^{-1}$ (Rekomendasi 100\% menurut Murni et al., 2010).

L3 = Pupuk organik cair dengan konsentrasi $5 \mathrm{ml} \mathrm{L}^{-1}$

L4 = Pupuk organik cair (konsentrasi $5 \mathrm{ml}$ $\left.\mathrm{L}^{-1}\right)+$ pupuk anorganik dengan dosis: Urea $300 \mathrm{~kg} \mathrm{ha}^{-1}$, SP-36 $150 \mathrm{~kg} \mathrm{ha}^{-1}$, dan $\mathrm{KCl} 100 \mathrm{~kg} \mathrm{ha}^{-1}$ (Rekomendasi $100 \%)$

L5 = Pupuk organik cair (konsentrasi $5 \mathrm{ml}$ $\left.\mathrm{L}^{-1}\right)$ + pupuk anorganik dengan dosis: Urea $180 \mathrm{~kg} \mathrm{ha}^{-1}$, SP-36 $90 \mathrm{~kg} \mathrm{ha}^{-1}$, dan $\mathrm{KCl} 60 \mathrm{~kg} \mathrm{ha}^{-1}$ (Rekomendasi 60\%)

L6 = Pupuk organik cair (konsentrasi $5 \mathrm{ml}$ $\left.\mathrm{L}^{-1}\right)+$ pupuk anorganik dengan dosis: Urea $60 \mathrm{~kg} \mathrm{ha}^{-1}$, SP-36 $30 \mathrm{~kg} \mathrm{ha}^{-1}$, dan $\mathrm{KCl} 20 \mathrm{~kg} \mathrm{ha}^{-1}$ (Rekomendasi 20\%)

Data yang diperoleh diuji homogenitasnya dengan Uji Bartlett, ketidakaditifan diuji dengan Uji Tukey, dan uji lanjutan dengan menggunakan uji beda nyata jujur (BNJ) 5\%. 
Lahan diolah dua kali kemudian dibuat petak perlakuan sebanyak enam petak dan diulang tiga kali sehingga jumlah petakan adalah 18 petak. Jarak antarpetak adalah 50 $\mathrm{cm}$. Ukuran petak yang diterapkan adalah $3 \mathrm{~m}$ x $2.5 \mathrm{~m}$.

Pupuk kompos kotoran ayam 5 ton ha ${ }^{-1}$ diaplikasikan pada seluruh petakan sebagai pupuk dasar organik. Pupuk organik cair diaplikasikan dengan cara disemprot pada daun dengan menggunakan konsentrasi $5 \mathrm{ml} \mathrm{L}^{-1}$. Aplikasi pupuk organik cair dilakukan pada 7 , 21, 35, dan 49 hari setelah tanam (HST). Volume semprot sesuai dengan yang direkomendasikan adalah $400 \mathrm{~L} \mathrm{ha}^{-1}$.

Penanaman benih dilakukan dengan menanam dua benih jagung manis pada setiap lubang tanam, lalu dilakukan penjarangan menjadi satu tanaman per lubang. Jarak tanam yang diterapkan adalah $70 \mathrm{~cm}$ x $20 \mathrm{~cm}$. Pupuk anorganik diaplikasikan pada larikan yang dibuat jarak $15 \mathrm{~cm}$ dari lubang tanam. Dosis pemberian pupuk sesuai perlakuan. Pupuk dasar berupa Urea (pemberian pertama), SP-36 dan $\mathrm{KCl}$ diberikan umur 7 HST oleh karena pada umur satu minggu akar jagung sudah mulai tumbuh. Aplikasi pupuk Urea kedua diberi pada 30 HST. Selama penelitian relatif terbebas dari hama dan penyakit. Pengendalian gulma dilakukan dengan cara mekanis.

Peubah-peubah yang diamati pada percobaan ini adalah (1) tinggi tanaman, (2) jumlah daun, (3) tingkat kehijauan daun dengan alat klorofil meter (SPAD), (4) bobot brangkasan kering oven, (5) serapan $\mathrm{N}$ daun saat vegetatif maksimum (rumus: kadar hara daun jagung manis (\%) $\mathrm{x}$ bobot kering (g)), (6) panjang tongkol, (7) panjang baris biji, (8) jumlah baris per tongkol, (9) jumlah biji per baris, (10) diameter tongkol, (11) bobot tongkol berkelobot, (12) bobot tongkol tanpa kelobot, (13) produksi total, (14) kandungan padatan terlarut ( ${ }^{\circ}$ Brix), diukur dengan Refractometer, dan (15) susut bobot pascapanen tongkol berkelobot pada suhu ruang (kehilangan selama penyimpanan, storage loss) diukur dengan cara selisih bobot tongkol berkelobot setelah beberapa hari disimpan dari bobot tongkol berkelobot awal panen.

\section{HASIL DAN PEMBAHASAN}

Berdasarkan hasil analisis kimia tanah, dapat diketahui bahwa lahan percobaan memiliki kadar $\mathrm{pH} 6.23$ yang sesuai dengan syarat tumbuh tanaman jagung manis. K-total dan rasio $\mathrm{C} / \mathrm{N}$ tanah menunjukkan hasil sedang, sedangkan N-total, P-tersedia, dan persentase C-organik rendah (Balai Penelitian Tanah, 2005) (Tabel 1). Kondisi ini membuat tanaman dapat merespon pupuk dengan lebih baik.

Berdasarkan jumlah hari hujan dan ratarata curah hujan dari stasiun cuaca, pada bulan Desember 2015 berjumlah 14 hari/6.1 mm, pada bulan Januari 2016 berjumlah 13 hari/5.46 mm, pada bulan Februari 2016 berjumlah 19 hari/19.48 mm, dan pada bulan Maret 2016 berjumlah 11 hari/4 mm. Hal ini berarti kebutuhan air selama pertumbuhan tanaman tercukupi dari air hujan.

Analisis ragam menunjukkan bahwa perlakuan berpengaruh nyata terhadap peubah tinggi tanaman, jumlah daun, bobot brangkasan kering (Tabel 2), panjang tongkol, panjang baris biji, jumlah baris per tongkol, jumlah biji per baris, diameter tongkol (Tabel 3 ), bobot tongkol berkelobot, bobot tongkol tanpa kelobot, dan produksi total per petak atau per hektar (Tabel 4), sedangkan tingkat kehijauan daun dan serapan $\mathrm{N}$ daun (Tabel 2) tidak berpengaruh nyata.

Tabel 1. Hasil analisis kimia tanah sebelum percobaan (Laboratorium Ilmu Tanah Fakultas Pertanian Universitas Lampung, 2015)

\begin{tabular}{lcc}
\hline Parameter & Hasil Analisis & Kriteria *) \\
\hline pH Tanah & 6.23 & Agak masam \\
N-total $(\%)$ & 0.15 & Sangat rendah \\
P-tersedia $(\mathrm{ppm})$ & 5.31 & Rendah \\
K-total $\left(\right.$ me $\left.100 \mathrm{~g}^{-1}\right)$ & 0.82 & Sedang \\
C/N & 9.67 & Sedang \\
C-organik $(\%)$ & 1.45 & Rendah \\
\hline
\end{tabular}

Sumber: *Balai Penelitian Tanah (2005). 
Pengaruh kombinasi pupuk organik cair dan pupuk anorganik terhadap peubah tinggi tanaman menunjukkan bahwa perlakuan pupuk organik cair dengan $60 \%$ dosis N, P, K rekomendasi (L5) memberikan pengaruh lebih baik daripada kontrol (L1) (Tabel 2). Bertambah tingginya tanaman karena aplikasi pupuk cair hayati sesuai dengan hasil penelitian Kartika et al., (2016) pada tanaman kemangi.

Pengaruh kombinasi pupuk organik cair dan pupuk anorganik terhadap peubah jumlah daun menunjukkan bahwa semua perlakuan memberikan pengaruh lebih baik daripada kontrol (L1) kecuali perlakuan kombinasi pupuk organik cair dan pupuk anorganik dengan dosis $20 \%$ (L6) (Tabel 2). Aplikasi taraf pemupukan tidak nyata memberikan pengaruh terhadap tingkat kehijauan daun maupun serapan $\mathrm{N}$ daun (Tabel 2). Hal ini karena tanaman lebih cenderung memanfaatkan serapan $\mathrm{N}$ untuk pertumbuhan vegetatif yang lain, misalnya pembesaran diameter batang dan penambahan jumlah daun tanaman. Hal ini dibuktikan oleh perlakuan pupuk organik cair, pupuk anorganik maupun kombinasinya menghasilkan tanaman dengan bobot brangkasan kering yang lebih berat daripada perlakuan kontrol tanpa pupuk (Tabel 2). Mengel dan Kirkby (2001) berpendapat bahwa peningkatan bobot kering tanaman adalah salah satu ciri peningkatan serapan nitrogen pada tanaman.

Tabel 2. Tinggi tanaman, jumlah daun, tingkat kehijauan daun, bobot brangkasan kering dan serapan $\mathrm{N}$ daun pada berbagai taraf pupuk organik cair dan pupuk anorganik

\begin{tabular}{cccccc}
\hline Perlakuan & $\begin{array}{c}\text { Tinggi } \\
\text { Tanaman } \\
(37 \mathrm{HST}) \\
(\mathrm{cm})\end{array}$ & $\begin{array}{c}\text { Jumlah Daun } \\
(37 \mathrm{HST}) \\
(\text { helai/tan })\end{array}$ & $\begin{array}{c}\text { Tingkat } \\
\text { Kehijauan } \\
\text { Daun } \\
(52 \mathrm{HST})\end{array}$ & $\begin{array}{c}\text { Bobot } \\
\text { Brangkasan } \\
\text { Kering }(70 \\
\text { HST })(\mathrm{g} / \mathrm{tan})\end{array}$ & $\begin{array}{c}\text { Serapan N } \\
\text { Daun }(52 \\
\text { HST })(\%)\end{array}$ \\
\hline L1 & $39.53 \mathrm{~b}$ & $10.20 \mathrm{~b}$ & $44.75 \mathrm{a}$ & $128.41 \mathrm{~b}$ & $2.24 \mathrm{a}$ \\
L2 & $45.40 \mathrm{ab}$ & $11.27 \mathrm{a}$ & $48.35 \mathrm{a}$ & $161.59 \mathrm{a}$ & $2.68 \mathrm{a}$ \\
L3 & $47.53 \mathrm{ab}$ & $11.40 \mathrm{a}$ & $49.39 \mathrm{a}$ & $153.70 \mathrm{a}$ & $2.41 \mathrm{a}$ \\
L4 & $45.17 \mathrm{ab}$ & $11.40 \mathrm{a}$ & $46.63 \mathrm{a}$ & $160.96 \mathrm{a}$ & $2.63 \mathrm{a}$ \\
L5 & $48.42 \mathrm{a}$ & $11.53 \mathrm{a}$ & $47.23 \mathrm{a}$ & $164.67 \mathrm{a}$ & $2.52 \mathrm{a}$ \\
L6 & $44.23 \mathrm{ab}$ & $11.13 \mathrm{ab}$ & $46.09 \mathrm{a}$ & $156.74 \mathrm{a}$ & $2.45 \mathrm{a}$ \\
\hline BNJ 5\% & 7.71 & 0.96 & 8.15 & 15.68 & 0.67 \\
\hline
\end{tabular}

Keterangan: L1 = Kontrol (tanpa pupuk); L2 = Pupuk anorganik 100\% rekomendasi; L3 = Pupuk organik cair; L4 = Pupuk organik cair + pupuk anorganik $100 \%$ rekomendasi; L5 = Pupuk organik cair + pupuk anorganik $60 \%$ rekomendasi; L6 = Pupuk organik cair + pupuk anorganik 20\% rekomendasi.

Tabel 3. Panjang tongkol, panjang baris biji, jumlah baris per tongkol, jumlah biji per baris dan diameter tongkol pada berbagai taraf pupuk organik cair dan pupuk anorganik

\begin{tabular}{cccccc}
\hline Perlakuan & $\begin{array}{c}\text { Panjang } \\
\text { Tongkol }(\mathrm{cm})\end{array}$ & $\begin{array}{c}\text { Panjang Baris } \\
\text { Biji }(\mathrm{cm})\end{array}$ & $\begin{array}{c}\text { Jumlah Baris } \\
\text { per Tongkol }\end{array}$ & $\begin{array}{c}\text { Jumlah Biji } \\
\text { per Baris }\end{array}$ & $\begin{array}{c}\text { Diameter } \\
\text { Tongkol }(\mathrm{cm})\end{array}$ \\
\hline L1 & $19.30 \mathrm{~b}$ & $15.41 \mathrm{~b}$ & $12.93 \mathrm{a}$ & $35.33 \mathrm{~b}$ & $3.96 \mathrm{~b}$ \\
L2 & $21.40 \mathrm{a}$ & $18.17 \mathrm{a}$ & $13.80 \mathrm{a}$ & $39.13 \mathrm{ab}$ & $4.62 \mathrm{a}$ \\
L3 & $21.07 \mathrm{a}$ & $18.17 \mathrm{a}$ & $13.73 \mathrm{a}$ & $41.00 \mathrm{a}$ & $4.60 \mathrm{a}$ \\
L4 & $20.33 \mathrm{a}$ & $17.57 \mathrm{a}$ & $14.07 \mathrm{a}$ & $38.20 \mathrm{ab}$ & $4.59 \mathrm{a}$ \\
L5 & $20.10 \mathrm{ab}$ & $17.17 \mathrm{a}$ & $14.40 \mathrm{a}$ & $37.00 \mathrm{ab}$ & $4.53 \mathrm{a}$ \\
L6 & $21.07 \mathrm{a}$ & $18.63 \mathrm{a}$ & $14.00 \mathrm{a}$ & $40.47 \mathrm{a}$ & $4.65 \mathrm{a}$ \\
\hline BNJ 5\% & 1.17 & 2.05 & 2.18 & 4.45 & 8.15 \\
\hline
\end{tabular}

Keterangan: L1 = Kontrol (tanpa pupuk); L2 = Pupuk anorganik 100\% rekomendasi; L3 = Pupuk organik cair; L4 = Pupuk organik cair + pupuk anorganik $100 \%$ rekomendasi; L5 = Pupuk organik cair + pupuk anorganik $60 \%$ rekomendasi; L6 = Pupuk organik cair + pupuk anorganik 20\% rekomendasi. 
Tabel 4. Bobot tongkol berkelobot, bobot tongkol tanpa kelobot, produksi total pada berbagai taraf pupuk organik cair dan pupuk anorganik

\begin{tabular}{ccccc}
\hline \multirow{2}{*}{ Perlakuan } & Bobot Tongkol & Bobot Tongkol & \multicolumn{2}{c}{ Produksi Total } \\
\cline { 4 - 5 } & Berkelobot $(\mathrm{g})$ & Tanpa Kelobot $(\mathrm{g})$ & $(\mathrm{kg}$ per Petak) & $\left(\right.$ ton ha $\left.\mathrm{a}^{-1}\right)$ \\
\hline L1 & $293.33 \mathrm{~b}$ & $230.00 \mathrm{~b}$ & $8.84 \mathrm{~b}$ & $9.43 \mathrm{~b}$ \\
L2 & $378.33 \mathrm{a}$ & $288.33 \mathrm{a}$ & $12.08 \mathrm{a}$ & $12.88 \mathrm{a}$ \\
L3 & $363.33 \mathrm{a}$ & $288.33 \mathrm{a}$ & $11.62 \mathrm{a}$ & $12.39 \mathrm{a}$ \\
L4 & $353.33 \mathrm{a}$ & $275.00 \mathrm{a}$ & $11.24 \mathrm{a}$ & $11.99 \mathrm{a}$ \\
L5 & $350.00 \mathrm{a}$ & $268.33 \mathrm{a}$ & $12.10 \mathrm{a}$ & $12.91 \mathrm{a}$ \\
L6 & $381.67 \mathrm{a}$ & $295.00 \mathrm{a}$ & $12.24 \mathrm{a}$ & $13.06 \mathrm{a}$ \\
\hline BNJ 5\% & 57.28 & 50.00 & 2.00 & 2.14 \\
\hline
\end{tabular}

Keterangan: L1 = Kontrol (tanpa pupuk); L2 = Pupuk anorganik 100\% rekomendasi; L3 = Pupuk organik cair; L4 = Pupuk organik cair + pupuk anorganik 100\% rekomendasi; L5 = Pupuk organik cair + pupuk anorganik $60 \%$ rekomendasi; L6 = Pupuk organik cair + pupuk anorganik $20 \%$ rekomendasi

Berdasarkan deskripsi, varietas Talenta mampu menghasilkan produksi jagung manis sebanyak 13-18.4 ton $\mathrm{ha}^{-1}$. Pada percobaan ini, produksi jagung manis perlakuan pupuk organik cair + pupuk anorganik $20 \%$ rekomendasi (L6) berada pada kisaran deskripsi karakter jagung manis tersebut, yaitu $16.32 \pm 1.71$ ton $\mathrm{ha}^{-1}$, dan tidak berbeda dengan perlakuan L2, L3, L4, dan L5 (Tabel 4). Perlakuan pupuk organik cair + pupuk anorganik $20 \%$ rekomendasi (L6) memiliki keuntungan lebih karena dapat mengurangi penggunaan pupuk anorganik (Urea, SP-36, dan $\mathrm{KCl}$ ) sampai $80 \%$. Hasil penelitian ini didukung oleh Purwanti (2014) yang menyatakan bahwa kombinasi pupuk hayati dan pupuk $\mathrm{N}, \mathrm{P}, \mathrm{K}$ berpengaruh terhadap pertumbuhan dan hasil tanaman jagung manis varietas Talenta. Aplikasi pupuk hayati dan pupuk kimia terpadu mampu meningkatkan efisiensi penggunaan pupuk $P$ dengan mengurangi dosis pupuk (Simanungkalit, 2001). Dengan demikian aplikasi terpadu pupuk organik cair dan pupuk anorganik dosis rendah dibawah dosis rekomendasi adalah teknik budidaya yang dianjurkan pada budidaya jagung manis, sekaligus dapat mengurangi pencemaran lingkungan akibat pemberian pupuk anorganik yang berlebihan.

Aplikasi pupuk organik cair (L3) dapat menghasilkan produksi jagung manis yang sama secara statistik dengan perlakuan pupuk anorganik rekomendasi maupun kombinasinya. Hal ini diduga karena aplikasi pupuk organik cair dengan cara semprot sampai tanaman berumur 49 HST dapat meningkatkan aktivitas metabolisme tanaman dan merangsang tanaman menjadi lebih efektif dalam menyerap nutrisi sampai tanaman memasuki fase produksi. Kandungan hormon Auksin dan Gibbrellin dalam pupuk organik cair diduga memberikan pengaruh positif terhadap kemampuan tanaman dalam menyerap nutrisi serta meningkatkan keefektifan tanaman dalam menyerap nutrisi tersebut. Hal ini dibuktikan oleh perlakuan L3, L4, L5, dan L6 (Tabel 2) memberikan respon pertumbuhan yang sama, sehingga diduga tanaman dapat mencukupi kebutuhan unsur hara melalui pupuk organik cair yang diserap melalui daun dan memanfaatkan nutrisi yang tersedia dalam tanah dengan lebih optimum. Hasil percobaan Syofia et al. (2014) menunjukkan bahwa pupuk organik cair "Santamicro" konsentrasi 3 $\mathrm{ml} \mathrm{L}^{-1}$ air yang diaplikasikan dengan cara disemprot dapat memberikan hasil terbaik pada peubah panjang tongkol, diameter tongkol, berat tongkol per tanaman, dan berat tongkol per plot jagung manis varietas Jambore dan Bonanza.

Perlakuan pupuk organik cair (L3) dapat memberikan pengaruh positif terhadap produktivitas tanaman jagung manis. Produksi jagung manis dari perlakuan pupuk organik cair (L3) nyata tidak berbeda dengan perlakuan L2, L4, L5, dan L6 (Tabel 4). Pupuk organik cair yang digunakan pada percobaan ini mengandung mikroba yang bermanfaat bagi tanaman yaitu Azotobacter, Azospirillium, Rhyzobium, Aspergillus, Lactobacillus, Mychoriza, dan Saccharomyces. Mukhlis dan Lestari (2013) menyatakan bahwa mikroba dalam pupuk hayati dapat memproduksi hormon, terutama Indole Acetic Acid (IAA) yang dapat meningkatkan pertumbuhan tanaman. Pupuk hayati dapat meningkatkan efisiensi penggunaan pupuk NPK hingga 50\% pada tanaman jagung (Mukhlis dan Lestari, 
2013; Nasrolahzadeh et al., 2017) dan padi (Aryanto et al., 2015). Pada komoditi semangka, perlakuan yang hanya mengandalkan pupuk hayati saja, hasil tanamannya relatif lebih baik jika dibandingkan dengan yang diaplikasikan dengan standar pemupukan anorganik (Antonius dan Agustiyani, 2011). Dengan demikian dapat ditegaskan bahwa pupuk organik cair dapat dimanfaatkan guna peningkatan produksi tanaman dengan memperhatikan bahwa pupuk organik cair disemprotkan pada pagi hari sehingga tidak terpapar matahari terik. Mengingat masa simpan pupuk organik cair yang cukup singkat (short shelf-life) maka penyimpanan produk pupuk organik cair harus dalam suhu ruang dan tidak terkena sinar matahari langsung.
Panjang baris biji, jumlah biji per baris, dan diameter tongkol menentukan bobot tongkol jagung manis dan produksi total per petaknya. Hal ini dapat dibuktikan melalui uji korelasi pada peubah generatif. Berdasarkan pengujian, panjang baris biji, jumlah biji per baris, dan diameter tongkol menunjukkan korelasi yang sangat nyata terhadap produksi total tongkol berkelobot per petak. Di samping itu, peubah tinggi tanaman dan bobot brangkasan kering tanaman juga memiliki korelasi yang sangat nyata terhadap produksi total tongkol berkelobot per petak (Tabel 5). Dari hasil uji korelasi, produksi total jagung manis ditentukan oleh peubah vegetatif seperti tinggi tanaman dan bobot brangkasan kering dan peubah generatif seperti panjang baris biji, jumlah biji perbaris dan diameter tongkol.

Tabel 5. Hasil uji korelasi peubah vegetatif dan generatif melalui uji korelasi Pearson

\begin{tabular}{|c|c|c|c|c|c|c|c|}
\hline Peubah & $\begin{array}{l}\text { Tinggi } \\
\text { Tanaman } \\
(\mathrm{cm})\end{array}$ & $\begin{array}{c}\text { Bobot } \\
\text { Brangkasan } \\
\text { Kering } \\
(\mathrm{g} / \mathrm{tan}) \\
\end{array}$ & $\begin{array}{c}\text { Panjang } \\
\text { Baris } \\
\text { Biji }(\mathrm{cm})\end{array}$ & $\begin{array}{c}\text { Jumlah } \\
\text { Baris Per } \\
\text { Tongkol }\end{array}$ & $\begin{array}{c}\text { Jumlah } \\
\text { Biji Per } \\
\text { Baris }\end{array}$ & $\begin{array}{c}\text { Diameter } \\
\text { Tongkol } \\
\text { (cm) }\end{array}$ & $\begin{array}{c}\text { Produksi } \\
\text { Total } \\
\text { (kg per } \\
\text { petak) } \\
\end{array}$ \\
\hline \multirow{2}{*}{$\begin{array}{l}\text { Tinggi } \\
\text { Tanaman } \\
(\mathrm{cm})\end{array}$} & \multirow{2}{*}{1} & $0.658 * *$ & $0.471^{*}$ & $0.498^{*}$ & $0.484 *$ & $0.673^{* *}$ & $0.656^{* *}$ \\
\hline & & 0.003 & 0.048 & 0.36 & 0.042 & 0.002 & 0.003 \\
\hline \multirow{2}{*}{$\begin{array}{l}\text { Bobot } \\
\text { Brangkasan } \\
\text { Kering } \\
\text { (g/tan) }\end{array}$} & $0.658^{* *}$ & \multirow{2}{*}{1} & $0.589^{*}$ & $0.510^{*}$ & 0.429 & $0.801 * *$ & $0.701 * *$ \\
\hline & 0.003 & & 0.010 & 0.030 & 0.076 & 0.000 & 0.001 \\
\hline \multirow{2}{*}{$\begin{array}{l}\text { Panjang } \\
\text { Baris Biji } \\
(\mathrm{cm})\end{array}$} & $0.471^{*}$ & $0.589 *$ & \multirow{2}{*}{1} & 0.289 & $0.801 * *$ & $0.820^{* *}$ & $0.738^{* *}$ \\
\hline & 0.048 & 0.010 & & 0.244 & 0.000 & 0.000 & 0.000 \\
\hline \multirow{2}{*}{$\begin{array}{l}\text { Jumlah } \\
\text { Baris per } \\
\text { Tongkol }\end{array}$} & $0.498^{*}$ & $0.510^{*}$ & 0.289 & \multirow{2}{*}{1} & -0.007 & $0.516^{*}$ & 0.393 \\
\hline & 0.36 & 0.030 & 0.244 & & 0.978 & 0.29 & 0.107 \\
\hline \multirow{2}{*}{$\begin{array}{l}\text { Jumlah Biji } \\
\text { per Baris }\end{array}$} & $0.484^{*}$ & 0.429 & $0.801 * *$ & -0.007 & \multirow{2}{*}{1} & $0.642 * *$ & $0.612 * *$ \\
\hline & 0.042 & 0.076 & 0.000 & 0.978 & & 0.004 & 0.007 \\
\hline \multirow{2}{*}{$\begin{array}{l}\text { Diameter } \\
\text { Tongkol } \\
(\mathrm{cm})\end{array}$} & $0.673^{* *}$ & $0.801 * *$ & $0.820 * *$ & $0.516^{*}$ & $0.642 * *$ & \multirow{2}{*}{1} & $0.854 * *$ \\
\hline & 0.002 & 0.000 & 0.000 & 0.029 & 0.004 & & 0.000 \\
\hline \multirow{2}{*}{$\begin{array}{l}\text { Produksi } \\
\text { Total (kg } \\
\text { per petak) }\end{array}$} & $0.656^{* *}$ & $0.701 * *$ & $0.738^{* *}$ & 0.393 & $0.612 * *$ & $0.854 * *$ & \multirow{2}{*}{1} \\
\hline & 0.003 & 0.001 & 0.000 & 0.107 & 0.007 & 0.000 & \\
\hline
\end{tabular}


Jagung manis tetap melakukan respirasi walau telah dipetik, hal ini mengakibatkan kerusakan fisiologis yang mengacu pada perubahan kimiawi maupun perubahan fisik pada mutu jagung manis. Kandungan padatan terlarut adalah salah satu atribut kualitas jagung manis (Szymanek, 2009). Indikasi adanya perubahan kimiawi selama penyimpanan yaitu terjadinya penurunan kadar Brix yang drastis pada 5 dan 8 hari setelah panen (Tabel 6). Penurunan kadar Brix yang drastis menjadikan rasa manis jagung berkurang bahkan berangsur hilang. Berkurangnya rasa manis disebabkan proses metabolisme yang tak terkendali yang mengakibatkan perubahan kimiawi pada produk. Perubahan ini membawa produk masuk fase penuaan. Cadangan makanan yang disimpan seperti karbohidrat dalam buah sebagai persediaan bahan energi kemudian digunakan untuk melangsungkan keaktifan dari sisa hidupnya. Oleh karena itu dalam proses pematangan karbohidrat dan gula selalu berubah (Winarno, 2002). Selama respirasi berlangsung, terjadi pemecahan oksidatif substrat kompleks yang terdapat dalam sel seperti pati, gula, dan asam organik menjadi molekul yang lebih sederhana, antara lain $\mathrm{CO}_{2}$ dan $\mathrm{H}_{2} \mathrm{O}$, disertai produksi energi dan molekul lain yang dapat digunakan untuk reaksi sintesis (Gardjito et al., 2016).

Indikasi adanya perubahan fisik pada tongkol yaitu terjadi penurunan bobot pada 5 dan 8 hari setelah panen. Persentase penyusutan bobot semakin bertambah dari hari ke 5 hingga hari ke 8 setelah panen (Tabel 7). Susut bobot selama penyimpanan juga ditemukan pada penyimpanan cabai (Rachmawati et al., 2009) dan mentimun (Darsana et al., 2003). Susut bobot ini dipengaruhi oleh proses fiologis yang terjadi selama masa simpan, yaitu respirasi (Widaningrum et al., 2010). Devanesan et al. (2011) menegaskan bahwa faktor utama yang memiliki kontribusi kerusakan selama proses pascapanen adalah respirasi. Menurut Nurdjannah et al., (2014) proses transpirasi merupakan bagian dari proses respirasi yang terjadi selama penyimpanan dimana pada saat terjadinya pemecahan makromolekul kompleks menghasilkan air dalam bentuk uap.

Tabel 6. Kandungan padatan terlarut pada hari panen, dan 5, 8 hari setelah panen pada berbagai taraf pupuk organik cair dan pupuk anorganik

\begin{tabular}{cccc}
\hline \multirow{2}{*}{ Perlakuan } & \multicolumn{3}{c}{ Brix (\%) } \\
\cline { 2 - 4 } & $\mathrm{H}$ & $\mathrm{H}+5$ & $\mathrm{H}+8$ \\
\hline L1 & $10.11 \mathrm{~b}$ & 2.93 & 1.53 \\
L2 & $11.53 \mathrm{a}$ & 3.57 & 2.37 \\
L3 & $11.09 \mathrm{a}$ & 3.73 & 1.60 \\
L4 & $10.42 \mathrm{ab}$ & 3.73 & 1.87 \\
L5 & $11.22 \mathrm{a}$ & 3.33 & 1.60 \\
L6 & $11.67 \mathrm{a}$ & 4.00 & 2.40 \\
\hline BNJ 5\% & 0.85 & 1.81 & 2.13
\end{tabular}

Keterangan: L1 = Kontrol (tanpa pupuk); L2 = Pupuk anorganik $100 \%$ rekomendasi; L3 = Pupuk organik cair; L4 = Pupuk organik cair + pupuk anorganik $100 \%$ rekomendasi; L5 = Pupuk organik cair + pupuk anorganik $60 \%$ rekomendasi; L6 $=$ Pupuk organik cair + pupuk anorganik $20 \%$ rekomendasi.

Tabel 7. Bobot tongkol berkelobot pada waktu panen $(\mathrm{H}), \mathrm{H}+5, \mathrm{H}+8$ dan persentase susut bobotnya pada berbagai taraf pupuk organik cair dan pupuk anorganik

\begin{tabular}{|c|c|c|c|c|c|}
\hline \multirow{2}{*}{ Perlakuan } & \multicolumn{3}{|c|}{ Bobot Tongkol Berkelobot (g) } & \multicolumn{2}{|c|}{ Susut Bobot (\%) } \\
\hline & $\mathrm{H}$ & $\mathrm{H}+5$ & $\mathrm{H}+8$ & $\mathrm{H}+5$ & $\mathrm{H}+8$ \\
\hline L1 & $17.13 \mathrm{~b}$ & $15.75 \mathrm{~b}$ & $14.61 \mathrm{~b}$ & 8.0 & 14.7 \\
\hline L2 & $19.46 \mathrm{a}$ & $18.07 \mathrm{a}$ & $17.17 \mathrm{a}$ & 7.1 & 11.7 \\
\hline L3 & $19.07 \mathrm{a}$ & $17.73 \mathrm{a}$ & $16.71 \mathrm{ab}$ & 7.0 & 12.3 \\
\hline L4 & $18.80 \mathrm{a}$ & $17.37 \mathrm{a}$ & $16.18 \mathrm{ab}$ & 7.6 & 13.9 \\
\hline L5 & $18.70 \mathrm{a}$ & $17.19 \mathrm{ab}$ & $16.28 \mathrm{ab}$ & 8.0 & 12.9 \\
\hline L6 & $19.54 \mathrm{a}$ & $18.23 \mathrm{a}$ & $17.33 \mathrm{a}$ & 6.7 & 11.3 \\
\hline BNJ 5\% & 1.51 & 1.47 & 2.19 & - & - \\
\hline
\end{tabular}

Keterangan: L1 = Kontrol (tanpa pupuk); L2 = Pupuk anorganik 100\% rekomendasi; L3 = Pupuk organik cair; L4 = Pupuk organik cair + pupuk anorganik $100 \%$ rekomendasi; L5 = Pupuk organik cair + pupuk anorganik $60 \%$ rekomendasi; $L 6=$ Pupuk organik cair + pupuk anorganik $20 \%$ rekomendasi 
Rashid (2013) menyatakan dalam penelitiannya bahwa penurunan kualitas dari jagung adalah karena efek dari kelembaban, suhu, kondisi fisik, dan terutama penurunan metabolisme. Penyimpanan jagung manis pada penelitian ini berlangsung sampai 8 hari dan menunjukkan penurunan pascapanen kualitas yang signifikan. Jagung manis dapat disimpan selama 4-8 hari pada suhu $0{ }^{\circ} \mathrm{C}$ (Samad, 2006). Dengan demikian dapat ditegaskan dari penelitian ini bahwa penyimpanan tongkol jagung manis berkelobot pada suhu ruang sebaiknya dilakukan singkat tidak lebih dari 5 hari.

\section{KESIMPULAN}

Kombinasi pupuk organik cair dan pupuk anorganik (Urea, SP-36, dan $\mathrm{KCl}$ ) 20\% rekomendasi dapat menjadi pupuk alternatif jagung manis yang lebih ekonomis karena pertumbuhan dan produksinya sama dengan pupuk anorganik rekomendasi. Kombinasi ini juga menunjukkan penyusutan bobot tongkol paling rendah sehingga kualitas tongkol jagung manis dapat bertahan lebih lama daripada perlakuan lainnya.

\section{UCAPAN TERIMA KASIH}

Penulis mengucapkan terima kasih kepada Direktorat Jenderal Pendidikan Tinggi sehingga penelitian ini dapat dilaksanakan dibawah payung Penelitian Hibah Bersaing (PHB) program desentralisasi Universitas Lampung tahun anggaran 2015.

\section{DAFTAR PUSTAKA}

Antonius, S., Agustiyani. 2011. Pengaruh pupuk organik hayati yang mengandung mikroba bermanfaat terhadap pertumbuhan dan hasil panen tanaman semangka serta sifat biokimia tanahnya pada percobaan lapangan di MalinauKalimantan Timur. Berk. Penel. Hayati. 16: 203-206.

Aryanto, A., Triadiati, Sugiyanta. 2015. Pertumbuhan dan produksi padi sawah dan gogo dengan pemberian pupuk hayati berbasis bakteri pemacu tumbuh di tanah masam. J. Ilm. Pert. Indonesia. 20(3): 229-235

[BPS] Badan Pusat Statistik. 2015. Luas panen, produktivitas, dan produksi jagung manis menurut provinsi. http://www.bps.go.id. [8 Juni 2016].

[BPT] Balai Penelitian Tanah. 2005. Petunjuk Teknis Analisis Kimia Tanah, Tanaman, Air, dan Pupuk. Balai Penelitian Tanah. Bogor. 143 hlm.

Darsana, L., S.P. Wartoyo, Wahyuti, T. 2003. Pengaruh saat panen dan suhu penyimpanan terhadap umur simpan dan kualitas mentimun jepang (Cucumis sativus L.). Agrosains. 5(1): 1-12.

Datta, J. K., A. Banerjee, M.S. Sikdar, S. Gupta, N. K. Mondal. 2009. Impact of combined exposure of chemical, fertilizer, bio-fertilizer and compost on growth, physiology and productivity of Brassica campestries in old alluvial soil. J. Env. Biol. 30(5): 797-800.

Devanesan, J.N., A. Karuppiah, C.V.K. Abirami. 2011. Effect of storage temperature, $\mathrm{O}_{2}$ concentrations and variety on respiration of mangoes. J. Agrobio. 28(2): 119-128.

Gardjito, M., W. Handayani, R. Salfarino. 2016. Penanganan Segar Hortikultura untuk Penyimpanan dan Pemasaran. Penerbit Prenamedia. Jakarta. 506 hal.

Kartika, J.G., K. Suketi, N. Mayasari. 2016. Produksi biomassa dan minyak atsiri kemangi (Ocimum basilicum L.) pada berbagai dosis pupuk nitrogen dan pupuk cair hayati. J. Hort. Indonesia. 7(1): 56-62.

Mengel, K., E.A. Kirkby. 2001. Principles of Plant Nutrition. 5th Ed. Kluwer Academic Publ. London. 849 hal.

Mihov, M., I. Tringovska. 2010. Energy efficiency improvement of greenhouse tomato production by applying new 
biofertilizers. Bul. J. Agric. Sci. 16(4): 454458.

Mukhlis, Y. Lestari. 2013. Effect of biofertilizer "M-Star" on land productivity and growth of sweet corn in acid sulphate soil of swampland. J. Agriv. 35(3): 242-248.

Murni, A. M., J.M. Pasuquin, C. Witt. 2010. Site specific nutrient management for maize on Ultisols Lampung. J. Trop. Soils. 15(1): 49-54.

Nasrolahzadeh, S., A. Shirkhani, S.Z. Salmasi. 2017. Agronomic responses of maize to defi cit and adequate irrigation and levels of chemical fertilizers and bio fertilizers. Biosci. Biotech. Res. Comm. 10(1): 219-229.

Nurdjannah, R., Y.A. Purwanto, Sutrisno. 2014. Pengaruh jenis kemasan dan penyimpanan dingin terhadap mutu fisik cabai merah. J. Pascapanen. 11(1): 1929.

Purwanti, L., W. Sutari, Kusumiyati. 2014. Pengaruh konsentrasi pupuk hayati dan dosis pupuk $\mathrm{N}, \mathrm{P}, \mathrm{K}$ terhadap pertumbuhan dan hasil tanaman jagung manis (Zea mays saccharata Sturt.) kultivar Talenta. Agric. Sci. J. 1(4): 177188.

Rachmawati, R., M.R. Defiani, N.L. Suriani. 2009. Pengaruh suhu dan lama penyimpanan terhadap kandungan vitamin c pada cabai rawit putih (Capsicum frustescens). J. Biol. 13(2): 36-40.

Ramana, V., M. Ramakrishna, K. Purushotham, K.B. Reddy. 2011. Effect of bio-fertilizers on growth, yield and quality of french bean (Phaseolus vulgaris $\mathrm{L}$.). Veg. Sci. 38(1): 35-38
Rashid, S., R. Kurt, A. Bern, Carl. 2013. Effects of deterioration parameters on storage of maize: A Review. J. Nat. Sci. Res. 3(9): 147-165.

Samad, M.Y. 2006. Pengaruh penanganan pasca panen terhadap mutu komoditas hortikultura. J. Sains Teknol. Indonesia. 8(1): 31-36.

Simanungkalit, R.D.M. 2001. Aplikasi pupuk hayati dan pupuk kimia: Suatu pendekatan terpadu. Bul. AgroBio. 4(2): 56-61.

Syofia, I., A. Munar, M. Sofyan. 2014. Pengaruh pupuk organik cair terhadap pertumbuhan dan hasil dua varietas tanaman jagung manis (Zea mays saccharata Sturt). J. Agrium. 18(3): 208-218.

Szymanek, M. 2009. Influence of sweet corn harvest date on kernels quality. Res. Agr. Eng. 55(1): 10-17

Utomo, M., T. Sabrina, Sudarsono, J. Lumbanraja, B. Rusman, Wawan. 2016. Ilmu Tanah: Dasar-dasar dan Pengelolaan. Kencana, Prenada Media Group. Jakarta. 433 hal.

Wachjar, A., Supijatno, D. Rubiana. 2006. Pengaruh beberapa jenis pupuk hayati terhadap pertumbuhan dua klon tanaman teh (Camellia sinensis (L) O. Kuntze) belum menghasilkan. Bul. Agron. 34(3): 160-164.

Widaningrum, Miskiyah, A.S. Somantri. 2010. Perubahan sifat fisiko-kimia biji jagung (Zea mays L.) pada penyimpanan dengan perlakuan karbondioksida $\left(\mathrm{CO}_{2}\right)$. Agritech. 30(1): 36-45.

Winarno, F.G. 2002. Fisiologi Lepas Panen Produk Hortikultura. Mbrio Press. Bogor. 202 hal. 